\title{
Seasonal Variability of Heavy Metals in Manchar Lake of Arid Southern Pakistan and Its Consequential Human Health Risk
}

\author{
Uzma Imran ${ }^{1 *}$, Rasool Bux Mahar', Asmat Ullah ${ }^{1,2,3}$, Kaleemullah Shaikh ${ }^{4}$ \\ ${ }^{1}$ US Pakistan Center for Advanced Studies in Water, Mehran University of Engineering and Technology, \\ Jamshoro, 76062, Sindh, Pakistan
}

${ }^{2}$ The Joint Graduate School of Energy and Environment (JGSEE), King Mongkut's University of Technology Thonburi (KMUTT), 126 Pracha Uthit Rd., Bang Mod, Thung Khru, Bangkok 10140, Thailand ${ }^{3}$ Centre of Excellence on Energy, Technology and Environment, PERDO, Bangkok, Thailand

${ }^{4}$ Faculty of Engineering, Balochistan University of Information Technology, Engineering, and Management Sciences (BUITEMS), Quetta, Balochistan, Pakistan

Received: 22 February 2020

Accepted: 9 April 2020

\begin{abstract}
Water pollution related to trace elements has emerged as a worldwide concern owing to their increasing concentration and damages to the aquatic ecosystems. The water ecosystem of Manchar Lake situated in the arid region of Pakistan has also been degraded and posing a severe health risk to the dependent communities. This study aims to investigate the seasonal variability in the influx of trace elements (As, Cd, $\mathrm{Cr}(\mathrm{III}), \mathrm{Cr}(\mathrm{VI}), \mathrm{Cu}, \mathrm{Fe}, \mathrm{Hg}, \mathrm{Mn}, \mathrm{Ni}, \mathrm{Pb}$, and $\mathrm{Zn}$ ) into the lake during premonsoon, monsoon, and post-monsoon seasons and its consequential health risks. The highest mean concentrations ( $\mu \mathrm{g} / \mathrm{l}$ ) of As (43.2), Cr(III) (101.4), Zn (41), Cu (43.12), Fe (318), Cd (18.5), Mn (27.2), $\mathrm{Ni}$ (99.7), $\mathrm{Pb}$ (65.91) and $\mathrm{Hg}(6.8)$ have been observed in pre-monsoon and $\mathrm{Cr}(\mathrm{VI})(0.2)$ in monsoon seasons. The elements exceeding safe limits in pre-monsoon season are $\mathrm{As}, \mathrm{Cd}, \mathrm{Cr}(\mathrm{III}), \mathrm{Hg}, \mathrm{Ni}$, and $\mathrm{Pb}$, while in monsoon season $\mathrm{As}, \mathrm{Cd}, \mathrm{Ni}$, and $\mathrm{Pb}$ exceed the limit. Evaluation of the degree of contamination depicted high levels of pollution in pre-monsoon and monsoon seasons and the Heavy Metal Evaluation Index indicated a high level of pollution in pre-monsoon, medium in monsoon, and low in the postmonsoon season. The study revealed that oral consumption of lake water potentially causes carcinogenic and non-carcinogenic health risks. However, potential dermal related health risks associated with these metals concentrations in water are within the tolerable ranges. The findings of this study suggest prompt actions to control these pollutants influx into the lake.
\end{abstract}

Keywords: Manchar Lake, metals and metalloids, human health risk assessment, pollution assessment

*e-mail: uimran.uspcasw@faculty.muet.edu.pk 


\section{Introduction}

A serious environmental concern that has appealed worldwide attention, is the degraded quality of many freshwater bodies since these are potentially harmful to human health and to the ecosystem [1]. Particularly in developing countries, wetlands are under threat due to climate change and growing human populations coupled with industrial and agricultural intensifications and little attention has been paid to protect these environments [2]. These heavy metals and metalloids are contributed from various sources, including atmospheric precipitation, geologic weathering, agricultural runoffs, and domestic and industrial discharges [3]. However, in the recent era, the contribution of trace elements into the water bodies from the anthropogenic activities have surpassed natural sources [4]. Consequently, deteriorated water quality affects the services offered by the aquatic ecosystems directly to humans, agriculture, and tourism [5].

Pollution of the aquatic environment by heavy metals is of great concern due to their toxicity, long persistence, and bioaccumulation into the food chain [6]; as such, they are harmful to humans and the aquatic life [7]. These trace elements in water can affect the human body through oral ingestion and dermal exposure. Although the presence of certain trace elements within limits is necessary to maintain human health, their excess can be injurious [8]. The exposure of the human body to these elements may cause acute and chronic diseases and long-term contact with these metals can cause severe diseases such as Alzheimer's, Parkinson's, multiple sclerosis, and cancer [4].The problem of trace elements accumulation in an aquatic ecosystem is worst particularly in the freshwater bodies of arid regions. Less rainfall, continuous influx of pollutants from various sources and less frequent spilling away of water are the major factors contributing to the rise in metals concentrations. Gradually, these pollutants accumulate into the water bodies to a limit where it becomes difficult to restore the ecosystem easily, resulting in a continued and lasting hazard to the ecosystem [9, 10].

Manchar Lake in Sindh province of the arid region of Pakistan is an important freshwater lake that is facing these challenges. Its ecosystem has been gradually deteriorated, not only because of all these predominant factors but also due to a decline in the adequate freshwater inflows into the lake due to low rainfalls and higher evaporation losses. Consequently, the water quality of the lake has been degraded and it is not fit for human consumption. The deteriorated water quality of the lake has also affected the land productivity cultivated with the water from Manchar Lake, loss of lake dependent biodiversity, including migratory birds, and this has ultimately affected the livelihood of the farmers and the fishermen [11].

Currently, Manchar Lake receives water through three sources, i.e. (i) the rainwater from the catchment area in the west of Sindh province and southeastern
Baluchistan province through the Gaj River and numerous other streams originating from the Khirthar and the Lakki range of mountains, (ii) River Indus inflows during high flood seasons through the Aral wah (canal) and Danister wah (canal) and (iii) the Main Nara Valley Drain (MNVD). Aral wah brings water into the Manchar Lake during summer high flood and drains out the lake water into the river Indus during low flow and it serves as two ways flow. However, during the study period, Aral wah was flowing from Manchar to Indus river in monsoon and post-monsoon seasons due to high water level in Manchar lake. MNVD was supplemented in 1932, initially as a flood canal but later remodeled to bring agricultural and municipal wastewater from upper Sindh to provide additional water to the lake during the dry season and it is responsible for the highest pollution influx. Besides, the lake also receives untreated domestic wastewater round the year from the surrounding villages.

The Manchar lake water is used for drinking purposes by the communities living in boat villages as well as on the banks of the lake. It is the only source of water to them because the groundwater in the vicinity is saline and not fit for human consumption [12]. The Reverse Osmosis (RO) plants installed by the government to treat lake water are mainly nonoperational and also not sufficient to meet the drinking water demand of the inhabitants.

Studies conducted in Manchar Lake suggest pollution of the lake with metals and metalloids [13, 14]. Due to the increasing water demand of other sectors and declined flows of Indus River, Manchar Lake has not been receiving much water from River Indus during the last few years. MNVD, carrying a certain level of pollutants, is continuously flowing into the lake. Besides, not much volume of water is spilling away from the lake which could have drained a certain quantity of contaminants and might help to improve the water quality. Therefore, it has been hypothesized that due to these factors, the water quality of Manchar Lake has been degraded significantly and posing a severe health risk to the dependent communities. Thus, the current study aims to (1) evaluate the concentration of trace elements (As, Cd, $\mathrm{Cr}(\mathrm{III}), \mathrm{Cr}(\mathrm{VI}), \mathrm{Cu}, \mathrm{Fe}, \mathrm{Hg}$, $\mathrm{Mn}, \mathrm{Ni}, \mathrm{Pb}$, and $\mathrm{Zn}$ ) of the lake water during different seasons in a year; (2) assess the pollution status of surface water; (3) determine the non-carcinogenic and carcinogenic risks for populations exposed to heavy metals and the metalloid.

\section{Materials and Methods}

\section{Description of the Study Area}

Manchar Lake is located in Sindh Province of Pakistan at a distance of around $18 \mathrm{~km}$ from the city of Sehwan Sharif, in district Jamshoro [15]. It lies at $67^{\circ} 34^{\prime}-67^{\circ} 43 \mathrm{E}$ and $26^{\circ} 23^{\prime}-26^{\circ} 28^{\prime} \mathrm{N}$, at an altitude of 


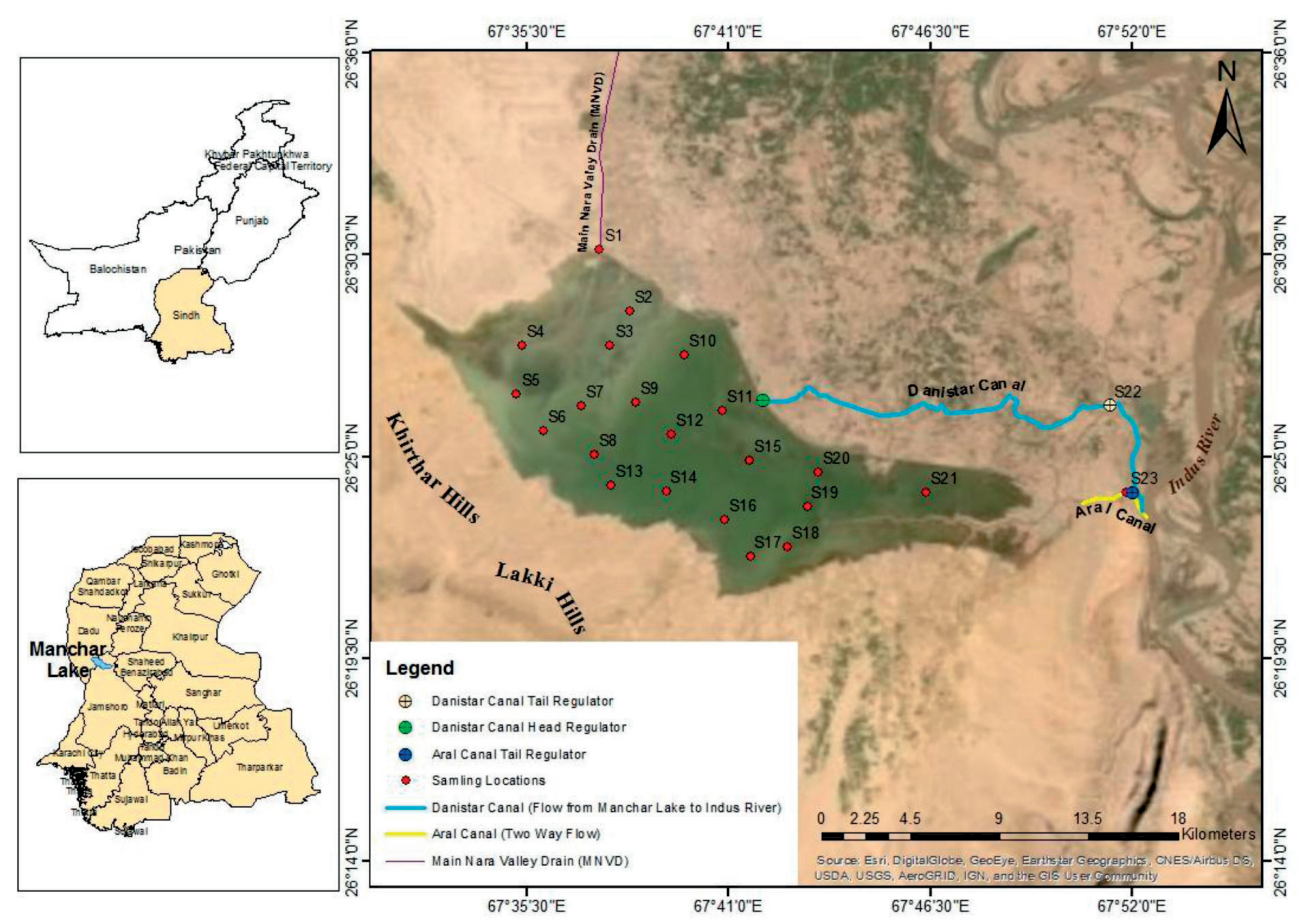

Fig. 1. Map showing the study area with sampling locations (Manchar Lake, Pakistan).

34.14 meters above mean sea level. The mean depth of the lake varies between 0.5 to $3.75 \mathrm{~m}$ [12] and its area fluctuates seasonally with average being $233 \mathrm{~km}^{2}$ [11]. It is a vast natural depression bordered in the west by the Khirthar hills, in the south by the Lakki hills and in the east by the Indus River as shown in Fig. 1 [15]. The original command of the lake has varied significantly due to various human interventions. These interventions include the erection and widening of the canals (Aral and Danister), connecting river Indus with the lake, the building of the flood barriers in 1932 in its northern and northeastern borders, and the construction of the MNVD, bringing polluted water from upper Sind into the lake [11].

\section{Sample Collection and Processing}

To determine the temporal variations of heavy metals (Cd, $\mathrm{Cr}(\mathrm{III}), \mathrm{Cr}(\mathrm{VI}), \mathrm{Cu}, \mathrm{Fe}, \mathrm{Hg}, \mathrm{Mn}, \mathrm{Ni}$, $\mathrm{Pb}$, and $\mathrm{Zn}$ ) and a metalloid (As) in lake water, 23 sampling locations were marked with the help of Global Positioning System (GPS) (Fig. 1), and the sampling was carried out in three seasons, i.e., premonsoon (April), monsoon (August) and post-monsoon (November) in 2019. The rationale for selecting many sampling sites was to precisely evaluate the spatial variations in metal concentrations across the entire lake.

Water samples were collected, handled, and transported by following standard methods [16]. Three replicate water samples were collected at each site from the surface $(0.153 \mathrm{~m}$ below top), mid and near the bottom ( $0.153 \mathrm{~m}$ above bottom) of the lake using a submersible pump (BC-MF double channel, Pedrollo, Italy) and each level replicates were combined into one sample in $300 \mathrm{ml}$ acid-washed polyethylene bottles. A total of 207 (including three samples at each location per round from 23 locations) water samples were collected to assess the concentration of trace elements. The water samples were immediately stored in ice boxes with ice pads and transported to the laboratory.

In the laboratory, water samples $(300 \mathrm{ml})$ were first divided into two subsamples $(200 \mathrm{ml}$ and $100 \mathrm{ml})$. Subsamples $(100 \mathrm{ml})$ for trace elements detection using Inductively Coupled Plasma Mass Spectrometry (ICPMS) were filtered through Maxipore syringe filters (pore size: $0.45 \mu \mathrm{m}$ ) to remove solid microparticles and were acidified with $1 \%$ analytical grade $\mathrm{HNO}_{3}$ (70 \% purity, DaeJung) to adjust $\mathrm{pH}<2$ $[17,18]$, to preserve trace elements in solution and avoid adsorption and precipitation. Remaining water samples $(200 \mathrm{ml})$ for $\mathrm{Cr}(\mathrm{VI})$ detection were added with the 1,5-diphenylcarbazide solution (Sigma-Aldrich, Germany) and sulfuric acid $\left(\mathrm{H}_{2} \mathrm{SO}_{4}, 95-98 \%\right.$, SigmaAldrich, Germany) to maintain $\mathrm{pH} 2 \pm 0.5$.

\section{Sample Analyses}

The concentrations of trace elements (As, Cd, total $\mathrm{Cr}, \mathrm{Cu}, \mathrm{Fe}, \mathrm{Hg}, \mathrm{Mn}, \mathrm{Ni}, \mathrm{Pb}$, and $\mathrm{Zn}$ ) in water samples were determined using Inductively Coupled Plasma Mass Spectrometry (ICPMS) (NexIon 350, Perkin Elmer, New York, USA) by following procedures recommended by manufacturers. Mixed standards solutions (PerkinElmer Pure Plus) were used for the 
calibration of the equipment. The concentrations of $\mathrm{Cr}(\mathrm{VI})$ in water samples were measured by using a UV spectrophotometer (Schimadzu UV 1800, Germany) at the wavelength of $540 \mathrm{~nm}$ as per the standard method of EPA (Method no. 7196A) [19] within 24 hours of sampling. The minimum detection limit (MDL) of the trace elements on an ICPMS and UV spectrophotometer were determined to be $0.001,0.0005,0.0005,0.0005$, $0.1,0.0005,0.002,0.0005,0.002$ and $0.001 \mu \mathrm{g} \cdot \mathrm{L}^{-1}$ for $\mathrm{As}, \mathrm{Pb}$, total $\mathrm{Cr}, \mathrm{Cd}, \mathrm{Cr}(\mathrm{VI}), \mathrm{Cu}, \mathrm{Fe}, \mathrm{Mn}, \mathrm{Ni}$, and $\mathrm{Hg}$ respectively. The concentration of $\mathrm{Cr}$ (III) was obtained by subtracting $\mathrm{Cr}(\mathrm{VI})$ from total $\mathrm{Cr}$.

\section{Quality Control (QC) and Quality Assurance (QA)}

Quality control and assurance measures were adopted as defined in Standard Methods for the Examination of Water and Wastewater [16] during sample collection and processing. The laboratory glassware were immersed in nitric acid (5\%) for 24 hours and rinsed three times with de-ionized water to avoid contamination. All equipment were calibrated each time before use. For analytical precision, each sample was analyzed in triplicate, and to control contamination during analyses, procedural blanks and duplicates run in each batch of ten samples were incorporated, and only certified standard reference materials were used for the calibration of the equipment. The recoveries of samples spiked with standards were observed to range from 95.2 to $102.1 \%$.

\section{Pollution Assessment}

In this study, two pollution indices i.e. degree of contamination $\left(\mathrm{C}_{\mathrm{deg}}\right)$ and the heavy metal evaluation index (HEI) were used to determine the quality of the water used for drinking and to meet the domestic and the agricultural needs. The $\mathrm{C}_{\mathrm{deg}}$ sums up the collective effects of elements studied that may degrade the water quality [3, 18, 20]; and was calculated by using Eq. 1.

$$
C_{d e g}=\sum_{i=1}^{n}\left(\frac{M_{i}}{M A C_{i}}-1\right)
$$

...where, $M_{i}$ and $M A C_{i}(10,3,50,50,1000,200,6,50$, 20, 1.5, and 10 in $\mu \mathrm{g} / 1$ for As, Cd, $\mathrm{Cr}(\mathrm{III}), \mathrm{Cr}(\mathrm{VI}), \mathrm{Cu}$,

$\mathrm{Fe}, \mathrm{Hg}, \mathrm{Mn}, \mathrm{Ni}, \mathrm{Pb}$, and $\mathrm{Zn}$ respectively [18] represents the monitored and the maximum admissible concentrations respectively for the $i^{\text {th }}$ element. Based on $\mathrm{C}_{\mathrm{deg}}$, a water body polluted with heavy metals is classified into various categories as: (low pollution when $\mathrm{C}_{\mathrm{deg}}$ is less than 1 , moderate pollution when $\mathrm{C}_{\mathrm{deg}}$ is between 1 and 3 and highly polluted when $\mathrm{C}_{\mathrm{deg}}$ is higher than 3). However, heavy metal evaluation index (HEI) describes the overall quality of water in terms of heavy metals and metalloids in an aquatic ecosystem $[3,18,21]$; and was calculated using Eq. 2 .

$$
H E I=\sum_{i=1}^{n} \frac{M_{i}}{M A C_{i}}
$$

The grouping of water quality based upon HEI is: (low pollution when HEI is lower than 10, moderate pollution when HEI is between 10-20 and highly polluted when HEI is higher than 20).

\section{Human Health Risk Assessment}

Due to saline groundwater in the vicinities [12] and poor performance of RO plants, the communities are left with no choice but to use the lake water without treatment. Consumption of water polluted with trace elements potentially harm the health of the communities and therefore, human health risk assessments were carried out to estimate the threats to an individual's health exposure to trace elements through water. The humans can be exposed to trace elements present in the water through various exposure routes, including oral intake as drinking water, dermal absorption through the skin, and inhalation through mouth and nose [22]. However, in this study only most common exposure pathways, i.e., oral ingestion of lake water as drinking water and dermal absorption during bathing, washing, or recreation in the lake were considered [23].

The chronic daily intake (CDI), which is the amount of pollutant ingested or adsorbed per kilogram of body weight per day $\left(\mathrm{mg} \cdot(\mathrm{kg} \cdot \mathrm{d})^{-1}\right)$, was calculated as shown in Eq. 3 and Eq. 4 for oral ingestion $\left(\mathrm{CDI}_{\text {oral }}\right)$ and for dermal absorption $\left(\mathrm{CDI}_{\text {dermal }}\right.$ ) respectively [24].

$$
\begin{gathered}
C D I_{\text {oral }}=\frac{C \times I R \times E F \times E D}{B W \times A T} \\
C D I_{\text {dermal }}=\frac{C \times S A \times E T \times P \times C F \times E F \times E D}{B W \times A T}
\end{gathered}
$$

...where $\mathrm{C}$ represents the mean concentrations $\left(\mathrm{mg} \cdot \mathrm{L}^{-1}\right)$ of metals and metalloid in the surface water. The values of all other parameters used in Eqs. 3 and 4 are given in Table 1.

To estimate the non-carcinogenic risk from exposure to water polluted with trace elements, the Hazard Quotient (HQ) was calculated for each trace element as shown in Eq. 5 [18, 25].

$$
H Q=\frac{C D I}{R f D}
$$

...where $\mathrm{R}_{\mathrm{f}} \mathrm{D}$ is the reference dose for oral and dermal exposure routes [26]. The values of $\mathrm{RfD}_{\text {oral }}$ and $\mathrm{RfD}_{\text {dermal }}$ are presented in Table 1 . At places where $\mathrm{RfD}_{\text {dermal }}$ values were not available, they were calculated by using Eq. 6 [27].

$$
R f D \text { dermal }=R f \text { Doral } \times G I A B S
$$

In this study, the values of gastrointestinal absorption factor (GIABS) used in calculations were 
Table 1. Values used in the calculation of CDI through different exposure routes.

\begin{tabular}{|c|c|c|c|}
\hline Parameters & Units & Values & References \\
\hline \multicolumn{4}{|c|}{ Body weight (BW) } \\
\hline Male & $\mathrm{Kg}$ & 78 & [29] \\
\hline Female & $\mathrm{Kg}$ & 66 & [29] \\
\hline Child & $\mathrm{Kg}$ & 32.7 & {$[30]$} \\
\hline \multicolumn{4}{|c|}{ Skin surface area (SA) } \\
\hline Male & $\mathrm{cm}^{2}$ & 18450 & {$[31]$} \\
\hline Female & $\mathrm{cm}^{2}$ & 16450 & {$[31]$} \\
\hline Child & $\mathrm{cm}^{2}$ & 10724 & {$[31]$} \\
\hline \multicolumn{4}{|c|}{ Water intake rate (IR) } \\
\hline Adult & $L \cdot d^{-1}$ & 2 & {$[31]$} \\
\hline Child & $L \cdot d^{-1}$ & 1 & {$[31]$} \\
\hline Exposure frequency (EF) & $d \cdot y^{-1}$ & 365 & {$[31]$} \\
\hline \multicolumn{4}{|c|}{ Exposure duration (ED) } \\
\hline Male & $\mathrm{Y}$ & 66 & {$[32]$} \\
\hline Female & Y & 67 & {$[32]$} \\
\hline Child & $\mathrm{Y}$ & 15 & {$[32]$} \\
\hline Averaging time (AT) & $\mathrm{EF} \times \mathrm{ED}$ & & \\
\hline \multicolumn{4}{|c|}{ Exposure time (ET), dermal } \\
\hline Adult & $\mathrm{hr} \cdot \mathrm{d}^{-1}$ & 0.58 & {$[25,33]$} \\
\hline Child & $\mathrm{hr} \cdot \mathrm{d}^{-1}$ & 1 & {$[34]$} \\
\hline Conversion factor (CF) & $\mathrm{cm}^{-3}$ & $1 \times 10^{-3}$ & {$[31]$} \\
\hline \multicolumn{4}{|c|}{ Permeability Coefficient (P) } \\
\hline As, $\mathrm{Cd}, \mathrm{Cr}(\mathrm{III}), \mathrm{Hg}, \mathrm{Mn}$ and $\mathrm{Zn}$ & $\mathrm{cm} \cdot \mathrm{h}^{-1}$ & $1 \times 10^{-3}$ & {$[25,27,35,36]$} \\
\hline $\mathrm{Ni}$ & $\mathrm{cm} \cdot \mathrm{h}^{-1}$ & $2 \times 10^{-4}$ & {$[25]$} \\
\hline $\mathrm{Cr}(\mathrm{VI})$ & $\mathrm{cm} \cdot \mathrm{h}^{-1}$ & $2 \times 10^{-3}$ & {$[25,36]$} \\
\hline \multicolumn{4}{|c|}{ Reference dose $\left(R_{f} D\right)$ oral/dermal } \\
\hline As & $\mathrm{mg} \cdot(\mathrm{kg} \cdot \mathrm{d})^{-1}$ & $3 \times 10^{-4} / 12.3 \times 10^{-5}$ & {$[24]$} \\
\hline $\mathrm{Cd}$ & $\mathrm{mg} \cdot(\mathrm{kg} \cdot \mathrm{d})^{-1}$ & $5 \times 10^{-4} / 2.5 \times 10^{-5}$ & {$[24]$} \\
\hline $\mathrm{Cr}(\mathrm{III})$ & $\mathrm{mg} \cdot(\mathrm{kg} \cdot \mathrm{d})^{-1}$ & $1.5 / 19.5 \times 10^{-3}$ & {$[24]$} \\
\hline $\mathrm{Cr}(\mathrm{VI})$ & $\mathrm{mg} \cdot(\mathrm{kg} \cdot \mathrm{d})^{-1}$ & $3 \times 10^{-3} / 7.5 \times 10^{-5}$ & {$[24]$} \\
\hline $\mathrm{Fe}$ & $\mathrm{mg} \cdot(\mathrm{kg} \cdot \mathrm{d})^{-1}$ & $0.3 / 0.14 \times 10^{-3}$ & {$[24]$} \\
\hline $\mathrm{Hg}$ & $\mathrm{mg} \cdot(\mathrm{kg} \cdot \mathrm{d})^{-1}$ & $3 \times 10^{-4} / 2.1 \times 10^{-5}$ & {$[24,25,27]$} \\
\hline $\mathrm{Mn}$ & $\mathrm{mg} \cdot(\mathrm{kg} \cdot \mathrm{d})^{-1}$ & $0.14 / 9.6 \times 10^{-4}$ & {$[24]$} \\
\hline $\mathrm{Ni}$ & $\mathrm{mg} \cdot(\mathrm{kg} \cdot \mathrm{d})^{-1}$ & $0.02 / 5.4 \times 10^{-3}$ & {$[24]$} \\
\hline $\mathrm{Pb}$ & $\mathrm{mg} \cdot(\mathrm{kg} \cdot \mathrm{d})^{-1}$ & $3.6 \times 10^{-3} / 4.2 \times 10^{-4}$ & {$[37]$} \\
\hline $\mathrm{Zn}$ & $\mathrm{mg} \cdot(\mathrm{kg} \cdot \mathrm{d})^{-1}$ & $0.3 / 6 \times 10^{-2}$ & {$[38]$} \\
\hline \multicolumn{4}{|c|}{ Slope factor (SF) oral/dermal } \\
\hline As & $\mathrm{kg} \cdot \mathrm{d} \cdot(\mathrm{mg})^{-1}$ & $1.5 / 3.66$ & [39] \\
\hline $\mathrm{Cr}(\mathrm{VI})$ & $\mathrm{kg} \cdot \mathrm{d} \cdot(\mathrm{mg})^{-1}$ & $0.5 / 20$ & {$[26]$} \\
\hline
\end{tabular}


$5 \times 10^{-2}, 1.3 \times 10^{-2}, 2.5 \times 10^{-2}$ and $7 \times 10^{-2}$ for $\mathrm{Cd}, \mathrm{Cr}(\mathrm{III})$, $\mathrm{Cr}(\mathrm{VI})$, and $\mathrm{Hg}$ respectively [27-29]. To determine the overall potential for non-carcinogenic health effects from exposure to lake water, the calculated HQ for every individual element $i$ was added to determine the Hazard Index (HI) for each exposure route was calculated using Eq. 7.

$$
H I i=H Q_{1}+H Q_{2}+H Q_{3}+\cdots+H Q_{n}
$$

...when $\mathrm{HQ} \geq 1$, heavy metals and metalloids may be related to a likely non-carcinogenic risk. The overall cancer risk (CR) from exposure to all individual elements in lake water was calculated by Eq. 8 [24].

$$
C R=C D I i \times S F i
$$

The values of slope factors are shown in Table 1. The $\mathrm{SF}_{\text {dermal }}$ for $\mathrm{Cr}(\mathrm{VI})$ was calculated by using Eq. 9 [27].

$$
\text { SFdermal }=\frac{\text { SForal }}{\text { GIABS }}
$$

At places where the concentrations of the measured metals and metalloid were lower than the MDL of ICPMS and UV Spectrophotometer, one-half the values of MDL were used for risk assessment calculations [30]. Since $\mathrm{Cr}(\mathrm{VI})$ was observed below analytical detection limits in all samples collected in the pre-monsoon season, as such carcinogenic and non-carcinogenic risks due to $\mathrm{Cr}(\mathrm{VI})$ in pre-monsoon season have not been considered.

\section{Principal Components and Cluster Analyses}

Principal component analysis (PCA) was used to develop fewer sets of components or factors that helped to investigate the relationships of the concentration of the metals. The number of components were identified using Eigenvalues coupled with parallel analysis. KaiserMeyer-Olkin (KMO) measure was used to confirm the sampling adequacy. Bartlett's Test was used to check if the correlation matric was significantly different from the identity matrix. Varimax rotation method was employed to identify the variables with high loading factors in each component. Hierarchical Cluster analysis (CA) was also performed to develop clusters of closely associated heavy metals using Ward's method. PCA and CA were performed using the Statistical Package for Social Sciences (SPSS).

\section{Results and Discussion}

\section{Temporal Variations of Trace Metals and a Metalloid}

Higher seasonal variability in water quality was observed due to more rainfall during the study period.
The mean concentrations and standard deviations of metals and a metalloid observed in Manchar Lake water by season are shown in Table 2. The highest concentrations of metals and the metalloid were noted at site 1, which is the inlet point of the lake represents the pollution status of MNVD which is the primary source of lake pollution.

It was observed that the overall concentrations of metals and the metalloid in water samples were in the order of $\mathrm{Fe}>\mathrm{Cr}$ (III) $>\mathrm{Ni}>\mathrm{Pb}>\mathrm{Zn}>\mathrm{As}$ $>\mathrm{Cu}>\mathrm{Mn}>\mathrm{Cd}>\mathrm{Hg}>\mathrm{Cr}(\mathrm{VI}), \mathrm{Fe}>\mathrm{Ni}>\mathrm{Cr}(\mathrm{III})>\mathrm{Pb}>\mathrm{Zn}>\mathrm{Cu}$ $>\mathrm{As}>\mathrm{Mn}>\mathrm{Cd}>\mathrm{Hg}>\mathrm{Cr}(\mathrm{VI})$, and $\mathrm{Fe}>\mathrm{Zn}>\mathrm{Pb}>\mathrm{Mn}>\mathrm{Cu}>\mathrm{Ni}$ $>\mathrm{As}>\mathrm{Cr}(\mathrm{III})>\mathrm{Cd}>\mathrm{Hg}>\mathrm{Cr}(\mathrm{VI}) \quad$ during pre-monsoon, monsoon and post-monsoon seasons, respectively. The observed highest mean concentrations $(\mu \mathrm{g} / \mathrm{l})$ of As (43.2), Cr III (101.4), Cu (43.12), Cd (18.5), Fe (318), $\mathrm{Hg}$ (6.8), Mn (27.2), Ni (99.7), Pb (65.91) and Zn (41) at various sampling locations in pre-monsoon and $\mathrm{Cr}(\mathrm{VI})$ (0.2) in monsoon seasons were more likely attributed to the anthropogenic activities including domestic wastewater discharges and irrigation return flows through MNVD.

Overall, the measured concentrations were observed to follow a trend of pre-monsoon $>$ monsoon $>$ postmonsoon, regardless of the sampling locations. It might be due to low water levels during the pre-monsoon season, with no freshwater inflows and continuous entry of pollution from MNVD, which thereby increases the overall concentrations of the trace elements. Similar findings were observed by Saleem et al. [18] that higher freshwater inflows due to rainfall during monsoon and post-monsoon season mix a considerable volume of non-contaminated water with the contaminated water to reduce total metal concentrations. Around $80 \%$ of annual rainfall in this region falls during monsoon season, which may dilute pollutants [18]. It is also interesting to note that due to an uneven rainfall pattern, the lake does not necessarily receive sufficient volume of freshwater each year. The average concentrations of heavy metals and the metalloid in lake water were compared with their respective permissible limits and it was observed that the concentration of $\mathrm{As}, \mathrm{Cd}$, $\mathrm{Cr}(\mathrm{III}), \mathrm{Hg}, \mathrm{Ni}$ and $\mathrm{Pb}$ were higher than permissible limits in pre-monsoon season; whereas $\mathrm{As}, \mathrm{Cd}, \mathrm{Ni}$ and $\mathrm{Pb}$ exceeded permissible limits in monsoon season. However, in post-monsoon season trace elements were observed within permissible limits, since rainfall continued in post-monsoon the year this study was conducted and the findings are in agreement with Mastoi et al. [13].

Average trace elements concentrations in Manchar Lake water were compared with previously reported literature on Manchar lake, and other Pakistani lakes reported levels in agricultural and municipal wastewater impacted lakes. In Manchar Lake, the concentrations of $\mathrm{Cd}, \mathrm{Cu}, \mathrm{Mn}, \mathrm{Ni}, \mathrm{Pb}$ and $\mathrm{Zn}$ were observed lower than the concentrations reported in other Pakistani lakes in all seasons, with one exception of lower concentrations of $\mathrm{Cd}, \mathrm{Cu}, \mathrm{Mn}, \mathrm{Ni}$ and $\mathrm{Zn}$ in 


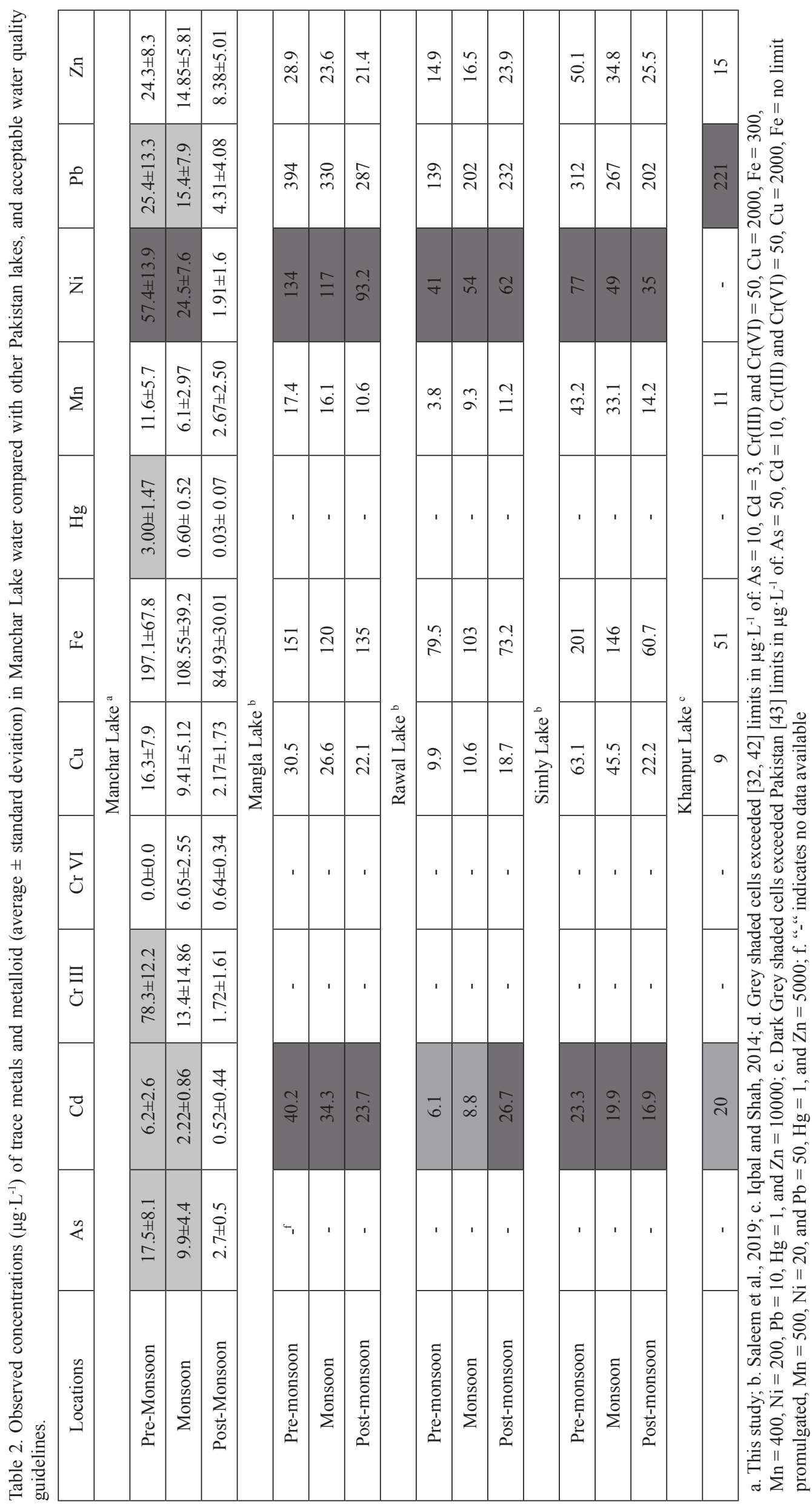


Table 3. Pollution assessment indices for trace elements in the Manchar Lake water.

\begin{tabular}{|c|c|c|c|c|c|c|}
\hline & \multicolumn{3}{|c|}{ HEI } & \multicolumn{3}{c|}{$C_{\text {deg }}$} \\
\hline & Pre-Monsoon & Monsoon & Post-Monsoon & Pre-Monsoon & Monsoon & Post-Monsoon \\
\hline & \multicolumn{3}{|c|}{$M_{i}$} & & $M_{i}$ \\
& \multicolumn{3}{|c|}{$M_{\text {ACi }}$} & \\
\hline $\mathrm{As}$ & 1.750 & 0.990 & 0.270 & 0.750 & -0.010 & -0.730 \\
\hline $\mathrm{Cd}$ & 2.067 & 0.740 & 0.173 & 1.067 & -0.260 & -0.827 \\
\hline $\mathrm{Cr}(\mathrm{III})$ & 1.566 & 0.268 & 0.034 & 0.566 & -0.732 & -0.966 \\
\hline $\mathrm{Cr}(\mathrm{VI})$ & 0.000 & 0.121 & 0.013 & -1.000 & -0.879 & -0.987 \\
\hline $\mathrm{Cu}$ & 0.016 & 0.009 & 0.002 & -0.984 & -0.991 & -0.998 \\
\hline $\mathrm{Fe}$ & 0.986 & 0.543 & 0.425 & -0.015 & -0.457 & -0.575 \\
\hline $\mathrm{Hg}$ & 3.000 & 0.60 & 0.030 & 2.000 & -0.400 & -0.970 \\
\hline $\mathrm{Mn}$ & 0.232 & 0.122 & 0.053 & -0.768 & -0.878 & -0.947 \\
\hline $\mathrm{Ni}$ & 2.870 & 1.225 & 0.096 & 1.870 & 0.225 & -0.905 \\
\hline $\mathrm{Pb}$ & 16.933 & 10.267 & 2.873 & 15.9 & 9.27 & 1.87 \\
\hline $\mathrm{Zn}$ & 2.430 & 1.485 & 0.838 & 1.430 & 0.485 & -0.162 \\
\hline $\mathrm{Total}$ & 31.850 & 16.370 & 4.808 & 20.850 & 5.370 & -6.192 \\
\hline
\end{tabular}

Rawal Lake during pre-monsoon season [18, 42]. In contrast, the Fe concentrations were higher in Manchar Lake than the levels reported in other Pakistan Lakes, except higher in Mangla lake during post-monsoon and the Simly lake during monsoon [18, 42]. However, the concentrations of Fe observed during the study period have been significantly lower than reported by Arain et al. [15], but is in agreement with Jahangir et al. [12]. The concentrations of trace elements including $\mathrm{As}, \mathrm{Fe}, \mathrm{Pb}$ and $\mathrm{Zn}$ as reported by Arain et al. [15] were observed as reduced, while $\mathrm{Cr}, \mathrm{Mn}$ and $\mathrm{Ni}$ were increased. However, no significant differences were observed in the concentrations of $\mathrm{Cd}$ and $\mathrm{Cu}$ as shown in Table 2.

\section{Pollution Assessment}

The pollution evaluation indices for trace metals and the metalloid in Manchar Lake water are shown in Table 3. The $\mathrm{C}_{\text {deg }}$ results revealed high levels of pollution (i.e., >3) in Manchar Lake water in the pre-monsoon and monsoon seasons but low-level contamination (i.e., less than 1) in the post-monsoon season. This is likely due to the lower concentrations of $\mathrm{Pb}$ in the post-monsoon season. However, using HEI, a high level of pollution (i.e., HEI $>20$ ) was observed in the pre-monsoon season, medium-level pollution in monsoon (i.e., 10-20) and a low level of pollution in post-monsoon (i.e., less than $10)$. a)

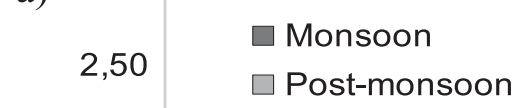

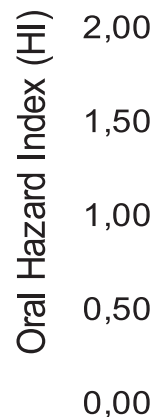
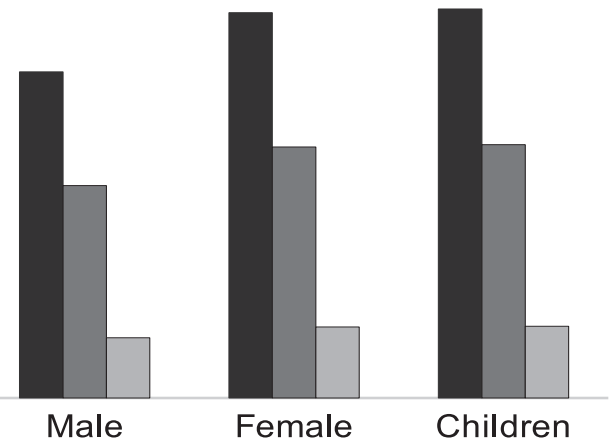

b)

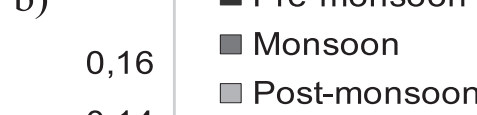

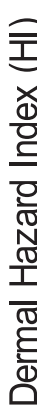

0,14

0,12

0,10

0,08

0,06

0,04

0,02

0,00
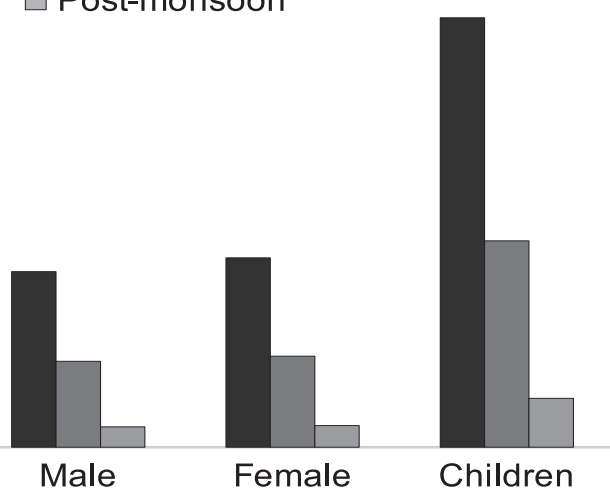

Fig. 2. Hazard index (HI) values for male, female and children in three seasons. a) Oral Hazard Index, b) Dermal Hazard Index. 
Health Risk Assessment

\section{Non-Carcinogenic Health Risk Assessment}

Ingestion and dermal absorption are regarded as the most critical impact paths of heavy metals and metalloid for human health. The oral hazard quotient $\left(\mathrm{HQ}_{\text {oral }}\right)$ and dermal hazard quotient $\left(\mathrm{HQ}_{\text {dermal }}\right)$ from exposure to water polluted with heavy metals and the metalloid were computed for male, female, and children separately for each season as shown in Fig. 2. The HI for each location was calculated as it is expected that the populations are usually using water near their residence. Generally, the absolute non-carcinogenic risk from exposure to Manchar Lake water arises from the consumption of water for drinking, as HI was $>1$. However, if the populations were to use an alternate source of drinking water and were only exposed to the water for recreation, bathing or washing, the noncarcinogenic risk from dermal contact was observed as acceptable for all males, females, and children.

\section{Carcinogenic Health Risk Assessment}

Cancer risk is defined as an increase in the probability that individuals will develop cancer over a lifetime due to exposure to a potentially carcinogenic substance [38]. The carcinogenic risk from exposure to water contaminated with $\mathrm{Cr}(\mathrm{VI})$ and As for male, female and children from oral and dermal paths of exposure were calculated as shown in Fig. 3. The major carcinogenic risk arises from oral exposure to As in water that is used for drinking with the probability of cancer risk exceeding $10^{-4}$ to $10^{-6}$ individuals for all males, females and children in all seasons. However, the cancer risk from $\mathrm{Cr}(\mathrm{VI})$ exists only in monsoon season. Nonetheless, if the lake water was used only for recreation, washing or bathing purposes, the likelihood of cancer exceeds 1 in 1,000,000 individuals except at location 1 in the pre-monsoon season. Therefore, the water cannot be considered fit to use in drinking.

\section{Relationships and Associations between Heavy Metals}

All three data sets including pre-monsoon, monsoon, and post-monsoon, were separately analyzed using PCA. The results of Kaiser-Meyer-Olkin (KMO) Measure of sampling adequacy and Bartlett's Test of Sphericity are shown in Table 4, confirm that the data is suitable to run PCA and investigate the principle components of each data set and their associated

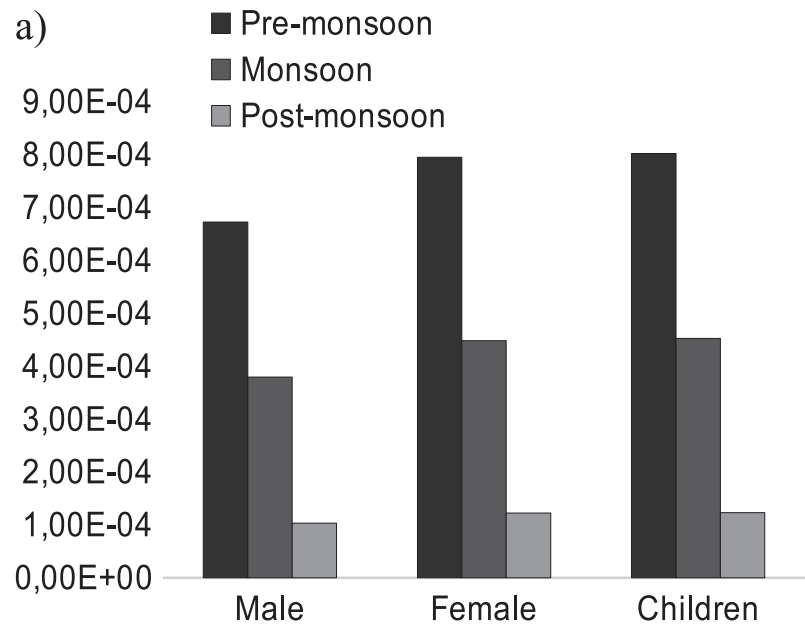

c)

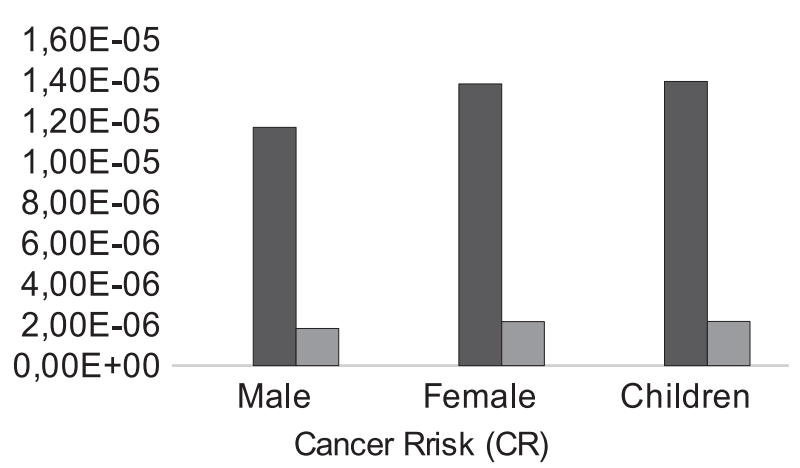

b)
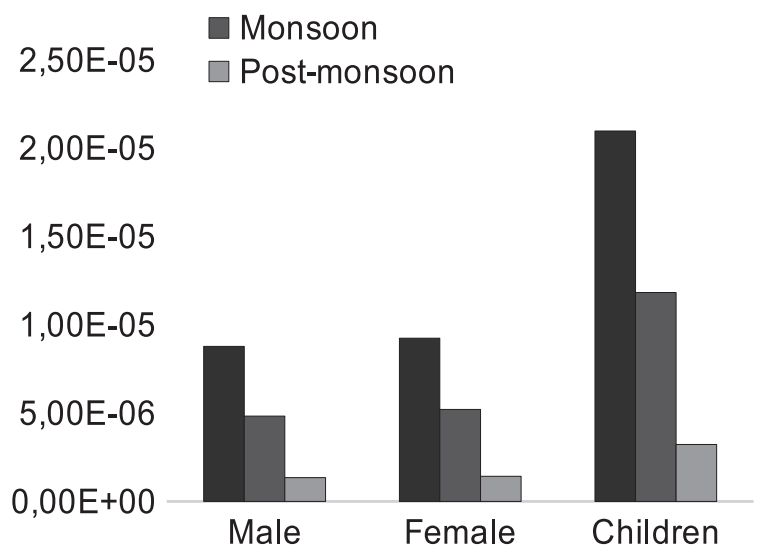

d)

1,40E-05

$1,20 \mathrm{E}-05$

$1,00 \mathrm{E}-05$

$8,00 \mathrm{E}-06$

$6,00 \mathrm{E}-06$

4,00E-06

2,00E-06

$0,00 \mathrm{E}+00$
Monsoon

$\square$ Post-monsoon

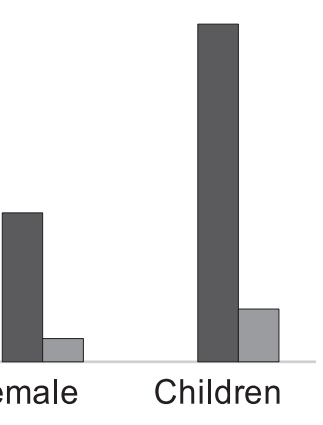

Fig. 3. Oral and dermal carcinogenic risk (plots a, b, c, and d,) from exposure to As and $\mathrm{Cr}(\mathrm{VI})$ in Manchar Lake water. 
Table 4. Component loading matrix of pre-monsoon, monsoon and post-monsoon metal concentration.

\begin{tabular}{|c|c|c|c|c|c|c|c|c|c|c|c|}
\hline & \multicolumn{3}{|c|}{ Pre-monsoon } & & \multicolumn{3}{|c|}{ Monsoon } & & \multicolumn{3}{|c|}{ Post-monsoon } \\
\hline & \multicolumn{3}{|c|}{ Components } & & \multicolumn{3}{|c|}{ Components } & & \multicolumn{3}{|c|}{ Components } \\
\hline Metals & PC-1 & PC-2 & PC-3 & Metals & PC-1 & PC-2 & PC-3 & Metals & PC-1 & PC-2 & PC-3 \\
\hline $\mathrm{Mn}$ & 0.848 & & & $\mathrm{Ni}$ & 0.828 & & & $\mathrm{~Pb}$ & 0.748 & & \\
\hline $\mathrm{Cd}$ & 0.761 & & & $\mathrm{Cu}$ & 0.603 & & & $\mathrm{Mn}$ & 0.73 & & \\
\hline As & 0.685 & & & As & -0.585 & & & $\mathrm{Hg}$ & 0.696 & & \\
\hline $\mathrm{Ni}$ & & 0.815 & & $\mathrm{Fe}$ & 0.564 & & & $\mathrm{Ni}$ & 0.589 & & \\
\hline $\mathrm{Fe}$ & & 0.618 & & $\mathrm{Cd}$ & & -0.700 & & $\mathrm{Fe}$ & & -0.769 & \\
\hline $\mathrm{Cu}$ & & 0.573 & & $\mathrm{Mn}$ & & 0.664 & & $\mathrm{Zn}$ & & 0.629 & \\
\hline $\mathrm{Cr}(\mathrm{III})$ & & 0.531 & & $\mathrm{~Pb}$ & & 0.584 & & $\mathrm{Cd}$ & & 0.557 & \\
\hline $\mathrm{Hg}$ & & & 0.703 & $\mathrm{Zn}$ & & -0.476 & 0.408 & As & & -0.411 & \\
\hline $\mathrm{Zn}$ & & & 0.688 & $\mathrm{Hg}$ & & & 0.775 & $\mathrm{Cu}$ & & & 0.836 \\
\hline $\mathrm{Pb}$ & & & 0.523 & $\mathrm{Cr}(\mathrm{III})$ & & & 0.718 & $\mathrm{Cr}(\mathrm{III})$ & & & 0.825 \\
\hline \multicolumn{3}{|c|}{ KMO Measure for sampling } & 0.628 & \multicolumn{3}{|c|}{ KMO Measure for sampling } & 0.570 & \multicolumn{3}{|c|}{ KMO Measure for sampling } & 0.567 \\
\hline \multicolumn{3}{|c|}{$\begin{array}{c}\text { Bartlett's Test of Sphericity } \\
\text { (Chi-Square value) }\end{array}$} & 154.443 & \multicolumn{3}{|c|}{$\begin{array}{l}\text { Bartlett's Test of Sphericity } \\
\text { (Chi-Square value) }\end{array}$} & 83.056 & \multicolumn{3}{|c|}{$\begin{array}{c}\text { Bartlett's Test of Sphericity } \\
\text { (Chi-Square value) }\end{array}$} & 120.125 \\
\hline & & P-value & 0.000 & & & P-value & 0.000 & & & P-value & 0.000 \\
\hline
\end{tabular}

characteristics. Three principal components of data of each season were determined using Eigenvalues $>1$ of the principal components followed by parallel analysis to keep a certain number of principal components. The principal components of pre-monsoon data explain more than $58 \%$ of the total variance, while the principal component of monsoon data explains about $51 \%$ and in post-monsoon explains about $55 \%$ of the total variance.

Considering the PCs of pre-monsoon data, PC1 explained about $28 \%$ of the total variance with a high loading of $\mathrm{Mn}, \mathrm{Cu}$, and As. However, PC2 explained around $17 \%$ of the variance with a high loading of $\mathrm{Ni}, \mathrm{Fe}, \mathrm{Cu}$ and $\mathrm{Cr}(\mathrm{III})$, while PC3 explained around $14 \%$ of the total variance with a high loading of $\mathrm{Hg}, \mathrm{Zn}$ and $\mathrm{Pb}$ as shown in Table 4. There is a negligible volume of freshwater flows into the lake during the pre-monsoon season; however, MNVD is the major source of pollutant influx from upstream. Besides, there is a certain level of pollutant influx into the lake from the surrounding farmlands and communities through drains which could be the possible reasons for correlations of these elements and variance in the water body.

Whereas, in case of monsoon, PC-1 explained $22 \%$ with a high loading of $\mathrm{Ni}, \mathrm{Cu}, \mathrm{As}$ and $\mathrm{Fe}, \mathrm{PC}-2$ explained $16 \%$ with a high loading of $\mathrm{Cd}, \mathrm{Mn}, \mathrm{Pb}$ and $\mathrm{Zn}$, and PC3 explained 12\% with a high loading of $\mathrm{Hg}$ and $\mathrm{Cr}(\mathrm{III})$ as shown in Table 4 . These results indicate that $\mathrm{As}$ and $\mathrm{Cd}$ gets diluted due to freshwater inflow due to monsoon floodwater; however, it is essential to know that monsoon flood water cause high variability of $\mathrm{Ni}, \mathrm{Cu}$, and $\mathrm{Fe}$ in the water body of the lake.
PCA results of post-monsoon data analysis indicate that PC-1 explained $22 \%$ of the variance with a high loading of $\mathrm{Pb}, \mathrm{Mn}, \mathrm{Hg}$, and $\mathrm{Ni}, \mathrm{PC}-2$ explains $21 \%$ of the variance with a high loading of $\mathrm{Cu}$ and $\mathrm{Cr}$ (III), and PC3 explained $13 \%$ of the variance with a high loading of $\mathrm{Fe}, \mathrm{Zn}$ and $\mathrm{Cd}$ as shown in Table 4. Post-monsoon variances of the metal concentration are the upshots of pollutants influx from upstream through monsoon floodwater.

Cluster analysis helps to determine the associations and similarities among trace elements and identifies homogenous groups of trace elements which are mutually correlated in the given data set. The dendrogram shown in Fig. 4 represents different clusters of the correlated heavy metals within each season separately (i.e., premonsoon, monsoon and post-monsoon). During premonsoon, cluster-1 represents $\mathrm{Cd}, \mathrm{Mn}, \mathrm{As}, \mathrm{Cd}$ and $\mathrm{Zn}$ with Hg. All four heavy metals in this cluster except As, are potentially being added either from locally untreated wastes into the lake, while As is possibly coming from geogenic sources. However, $\mathrm{Ni}, \mathrm{Pb}$ make cluster with $\mathrm{Cu}$ and $\mathrm{Fe}$. In terms of monsoon concentration, $\mathrm{Cu}, \mathrm{Ni}$, $\mathrm{Fe}, \mathrm{Mn}$ and $\mathrm{Pb}$ were observed as closely correlated and these are mostly from anthropogenic sources. Cr(III), $\mathrm{Hg}$ and $\mathrm{Zn}$ from another closely associated cluster getting accumulated from anthropogenic sources. The cluster representing $\mathrm{Cd}$ and As shows that during monsoon, these metals get diluted. In post-monsoon $\mathrm{Cr}$ (III) and $\mathrm{Cu}$ show a strong relationship and develop cluster 1 together with $\mathrm{Zn}$ and $\mathrm{Cd}$. In cluster 2, Mn, $\mathrm{Pb}, \mathrm{Hg}$ and $\mathrm{Ni}$ represents strong correlations. The third cluster represent $\mathrm{Fe}$ and As. The distributon and 


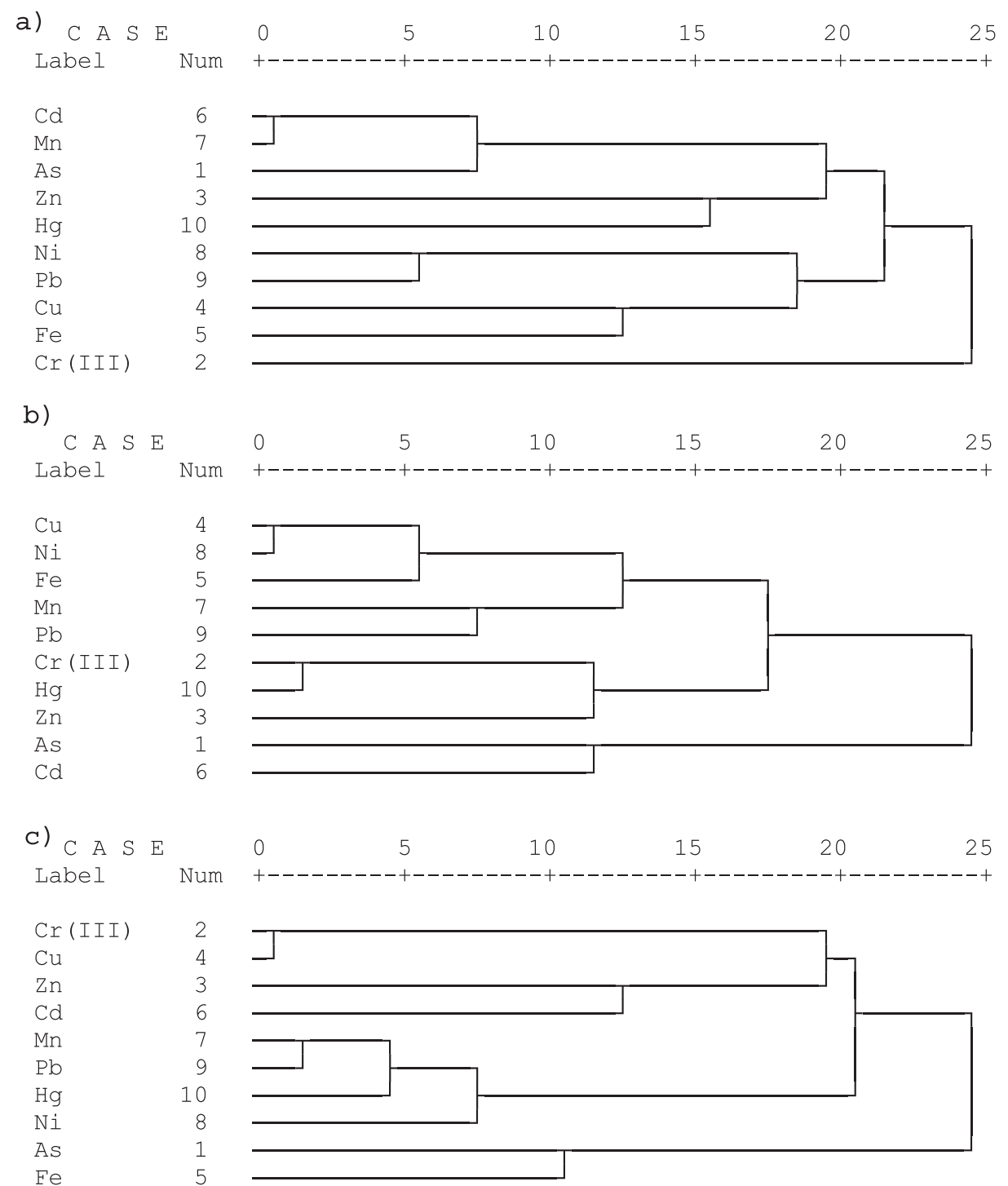

Fig. 4. Dendrogram displaying clusters of heavy metals as per seasons. a) Pre-Monsoon, b) Monsoon, c) Post-Monsoon.

relationship of the metals during post-monsoon depends on the volume and pollution level of drained water inflow into the lake.

\section{Limitations of the Study}

Human health risk assessments involve certain uncertainties and variability [43], resulting in under or overestimation of the risks, which necessitates to include a discussion of the limitations associated with such studies. The inconsistency in exposure estimation, like assuming exposure to an entire lifetime, may overestimate the duration of use of the Manchar Lake water and thus overestimated the risk. This study also involves an assumption that receptors do not travel and only use Manchar lake water without any treatment. Due to absence of Pakistan specific population data, exposure factors used in this study for calculations were from USEPA and WHO, which might not fit the real conditions and might led to either over (more skin surface area in USEPA guidelines) or under (excessive body weight in USEPA guidelines) estimation. The use of one half of the detection limit in samples where trace elements were not detected might result in an overestimation of risk. The study did not consider any treatment of the water before its use as drinking water. However, the use of RO plants, cloth filters, or letting the water-sediment settle before drinking may result in lower concentrations of metals, especially those associated with turbidity such as $\mathrm{Cu}$, $\mathrm{Fe}$, and $\mathrm{Mn}$.

\section{Conclusions}

In this study, the seasonal variability in heavy metals and metalloid concentration in Manchar Lake water has been observed. The anthropogenic wastewater inflow from the settlements and farmlands comprise a constant polluting source, whereas only monsoon rainfall-runoff occurs within the catchment 
might contribute a certain amount of metals from natural sources through water inflow into the lake. Results revealed that $\mathrm{As}, \mathrm{Cd}, \mathrm{Cr}(\mathrm{III}), \mathrm{Hg}, \mathrm{Ni}$, and $\mathrm{Pb}$ concentration are exceeding the recommended drinking water standards. Pollution assessment indices suggested a high level of pollution in the pre-monsoon season, medium-level pollution in monsoon and low level of pollution in post-monsoon due to dilution caused by freshwater inflows. Depending upon the amount of precipitation in a year, this medium and low-level pollution occurs only for a few months and then the concentrations start increasing. Being in the arid region, this high level of pollution remains for many months during the year. The health risk assessments based on average concentrations suggest the potential for adverse carcinogenic and non-carcinogenic effects on individuals using the water for drinking purposes. Nevertheless, water used for recreation, bathing or washing poses risk within the tolerable range. Overall, the results suggest that there is a need to manage and regulate the toxic pollutants entering the Manchar Lake, mainly from agricultural runoffs and urban domestic waste discharges, entering the lake through MNVD. The findings of this study will also inform residents and visitors to the lake regarding possible health threats from exposure to metalcontaminated water.

\section{Acknowledgements}

This study was funded by the US-Pakistan Center for Advanced Studies in Water (USPCAS-W), supported by the United States Agency for International Development (USAID). The authors would also like to thank USPCAS-W, Mehran University of Engineering and Technology (MUET) Jamshoro, Sindh, Pakistan, for providing laboratory facilities for carrying out this research.

\section{Conflict of Interest}

The authors declare no conflict of interest.

\section{References}

1. EMENIKE P.C., NERIS J.B., TENEBE I.T., NNAJI C.C., JARVIS P. Estimation of some trace metal pollutants in River Atuwara southwestern Nigeria and spatio-temporal human health risks assessment. Chemosphere, 239, 124770, 2020.

2. IMRAN U., ULLAH A., SHAIKH K., MEHMOOD R., SAEED M. Health risk assessment of the exposure of heavy metal contamination in surface water of lower Sindh, Pakistan. SN Applied Sciences, 1 (6), 1, 2019.

3. KUMAR V., PARIHAR R.D., SHARMA A., BAKSHI P., SINGH SIDHU G.P., BALI A.S., KARAOUZAS I., BHARDWAJ R., THUKRAL A.K., GYASI-AGYEI
Y., RODRIGO-COMINO J. Global evaluation of heavy metal content in surface water bodies: A meta-analysis using heavy metal pollution indices and multivariate statistical analyses. Chemosphere, 236, 124364, 2019.

4. SAHA P., PAUL B. Assessment of heavy metal toxicity related with human health risk in the surface water of an industrialized area by a novel technique. Human and Ecological Risk Assessment: An International Journal, 25 (4), 966, 2019.

5. NAWAB J., KHAN S., XIAOPING W. Ecological and health risk assessment of potentially toxic elements in the major rivers of Pakistan: General population vs. Fishermen. Chemosphere, 202, 154, 2018.

6. YIN K., WANG Q., LV M., CHEN L. Microorganism remediation strategies towards heavy metals. Chemical Engineering Journal, 360, 1553, 2019.

7. WANG X., ZHANG L., ZHAO Z., CAI Y. Heavy metal pollution in reservoirs in the hilly area of southern China: Distribution, source apportionment and health risk assessment. Science of the Total Environment, 634, 158, 2018.

8. BODAGHPOUR S., BIGLARIJOO N., AHMADI S. A review on the existence of chrome in cement and environmental remedies to control its effects. International Journal of Geology, 6 (2), 62, 2012.

9. ZHANG Z., JUYING L., MAMAT Z., QINFU Y. Sources identification and pollution evaluation of heavy metals in the surface sediments of Bortala River, Northwest China. Ecotoxicology and Environmental Safety, 126, 94, 2016.

10. Zhaoyong Z., Xiaodong Y., Shengtian Y. Heavy metal pollution assessment, source identification, and health risk evaluation in Aibi Lake of northwest China. Environmental Monitoring and Assessment, 190 (2), 1, 2018.

11. KAZI T.G., ARAIN M.B., JAMALI M.K., JALBANI N., AFRIDI H.I., SARFRAZ R.A., BAIG J.A., SHAH A.Q. Assessment of water quality of polluted lake using multivariate statistical techniques: A case study. Ecotoxicology and Environmental Safety, 72 (2), 301, 2009.

12. JAHANGIR T.M., KHUHAWAR M.Y., LEGHARI S.M., MAHAR M.T., MAHAR K.P. Water quality and sediment assessment of Manchar Lake, Sindh, Pakistan: after effects of the super flood of 2010. Arabian Journal of Geosciences, 8 (5), 3259, 2014.

13. MASTOI G.M., SHAH S.G.S., KHUHAQAR M.Y. Assessment of water quality of Manchar Lake in Sindh (Pakistan). Environmental Monitoring and Assessment, 141 (1-3), 287, 2008

14. ARAIN M.B., KAZI T.G., JAMALI M.K., JALBANI N., AFRIDI H.I., SHAH A. Total dissolved and bioavailable elements in water and sediment samples and their accumulation in Oreochromis mossambicus of polluted Manchar Lake. Chemosphere, 70 (10), 1845, 2008.

15. ARAIN M.B., KAZI T.G., JAMALI M.K., AFRIDI H.I., BAIG J.A., JALBANI N., SHAH A.Q. Evaluation of physico-chemical parameters of Manchar Lake water and their comparison with other global published values. Pak. J. Anal. Environ. Chem, 9 (2), 101. Retrieved from http:// pjaec.pk/index.php/pjaec/article/view/183, 2008.

16. RICE E.W., BAIRD R.B., EATON A.D., CLESCERI L.S. Standard Methods for the Examination of Water and Wastewater. American Public Health Association, American Water Works Association, Water Environment Federation ( $22^{\text {nd }}$ ed.). American Public Health Association, American Water Works Association, Water Environment Federation. 2012. 
17. VAROL M. Dissolved heavy metal concentrations of the Kralkizi, Dicle and Batman dam reservoirs in the Tigris River basin, Turkey. Chemosphere, 93 (6), 954, 2013.

18. SALEEM M., IQBAL J., SHAH M.H. Seasonal variations, risk assessment and multivariate analysis of trace metals in the freshwater reservoirs of Pakistan. Chemosphere, 216, 715, 2019.

19. US EPA (U.S. Environmental Protection Agency). EPA standard method for colorimetric determination of Hexavalent Chromium (Method-7196A). (n.d.)

20. IMRAN U., WEIDHAAS J., ULLAH A., SHAIKH K. Risk associated with spatio-temporal variations in trace metals and a metalloid in a major freshwater reservoir of Pakistan. Human and Ecological Risk Assessment, 1, 2020.

21. BHUIYAN M.A.H., DAMPARE S.B., ISLAM M.A., SUZUKI S. Source apportionment and pollution evaluation of heavy metals in water and sediments of Buriganga River, Bangladesh, using multivariate analysis and pollution evaluation indices. Environmental Monitoring and Assessment, 187 (1), 1, 2015.

22. CHEN L., ZHOU S., WU S., WANG C., HE D. Concentration, fluxes, risks, and sources of heavy metals in atmospheric deposition in the Lihe River watershed, Taihu region, eastern China. Environmental Pollution, 255, 112201, 2019.

23. QU L., HUANG H., XIA F., LIU Y., DAHLGREN R.A., ZHANG M., MEI K. Risk analysis of heavy metal concentration in surface waters across the ruralurban interface of the Wen-Rui Tang River, China. Environmental Pollution, 237, 639, 2018.

24. US EPA. Risk Assessment Guidance for Superfund (RAGS): Volume I - Human Health Evaluation Manual (Part D). Usepa (Vol. I). Washington, D.C. 20450: EPA/540/1-89/002. Retrieved from http://www.epa.gov/ sites/production/files/2015-09/documents/partf_200901_ final.pdf 1989.

25. IMRAN U., KHAN M., JAMAL R., SAHULKA S.Q., GOEL R., MAHAR R., WEIDHAAS J. Probabilistic risk assessment of water distribution system in Hyderabad, Pakistan reveals unacceptable health hazards and areas for rehabilitation. Ecotoxicology and Environmental Safety, 191, 110233, 2020.

26. US EPA. Edition of the drinking water standards and health advisories tables. Office of Water U.S. Environmental Protection Agency. Washington, DC: EPA 822-F-18-001: USEPA. 2018.

27. US EPA. Risk assessment guidance for superfund (RAGS). Volume I. Human health evaluation manual. Part E. Supplemental guidance for dermal risk assessment. United States Environmental Protection Agency. Washington, DC: EPA/540/R/99/005. 2004.

28. NAZ A., MISHRA B.K., GUPTA S.K. Human health risk assessment of chromium in drinking water: A case study of sukinda chromite mine, Odisha, India. Exposure and Health, 8 (2), 253, 2016.

29. QU L., HUANG H., XIA F., LIU Y., DAHLGREN R.A., ZHANG M., MEI K. Risk analysis of heavy metal concentration in surface waters across the ruralurban interface of the Wen-Rui Tang River, China. Environmental Pollution, 237, 639, 2018.

30. WU H., CHEN B. Using Statistical and Probabilistic Methods to Evaluate Health Risk Assessment: A Case Study. Toxics, 2 (2), 291, 2014.
31. US EPA. Exposure Factors Handbook (2011 th ed.). Washington DC: EPA/600/R-09/052F: National Technical Information Service, Springfield, VA. Retrieved from http://www.epa.gov/ncea/efh. 2011.

32. KHAN K., LU Y., KHAN H., ZAKIR S., IHSANULLAH KHAN S., KHAN A.A., WEI L., WANG T. Health risks associated with heavy metals in the drinking water of Swat, northern Pakistan. Journal of Environmental Sciences, 25 (10), 2003, 2013.

33. ATSDR. Public Health Assessment Guidance Manual. U.S. Department of Health and Human Services Public Health Service: Agency for Toxic Substances and Disease Registry Atlanta, Georgia. Atlanta, Georgia. 2005.

34. WHO. Guidelines for drinking-water quality: Forth edition incorporating the first addendum. Geneva. Retrieved from http://apps.who.int/iris/bitstre am/10665/254637/1/9789241549950-eng.pdf 2017.

35. NAZ A., MISHRA B.K., GUPTA S.K. Human health risk assessment of chromium in drinking water: A case study of Sukinda chromite mine, Odisha, India. Exposure and Health, 8 (2), 253, 2016.

36. KANSAL A., SIDDIQUI N.A., GAUTAM A. Assessment of heavy metals and their interrelationships with some physicochemical parameters in eco-efficient rivers of Himalayan region. Environmental Monitoring and Assessment, 185 (3), 2553, 2013.

37. KARIM Z. Risk assessment of dissolved trace metals in drinking water of Karachi, Pakistan. Bulletin of Environmental Contamination and Toxicology, 86 (6), 676, 2011.

38. OBIRI S., YEBOAH P.O., OSAE S., ADU-KUMI S., COBBINA S.J., ARMAH F.A., ASON B., ANTWI E., QUANSAH R. Human health risk assessment of artisanal miners exposed to toxic chemicals in water and sediments in the Prestea Huni Valley district of Ghana. International Journal of Environmental Research and Public Health, 13 (1), 1, 2016.

39. REHMAN I. UR, ISHAQ M., ALI L., KHAN S., AHMAD I., DIN I.U., ULLAH H. Enrichment, spatial distribution of potential ecological and human health risk assessment via toxic metals in soil and surface water ingestion in the vicinity of Sewakht mines, district Chitral, Northern Pakistan. Ecotoxicology and Environmental Safety, 154, 127, 2018.

40. MITRA S., SARKAR S.K., RAJA P., BISWAS J.K., MURUGAN K. Dissolved trace elements in Hooghly (Ganges) River Estuary, India: Risk assessment and implications for management. Marine Pollution Bulletin, 133 (May), 402, 2018.

41. RAIS. The Risk Assessment Information System (RAIS). Retrieved August 26, 2019, from https://rais.ornl.gov/tox/ profiles/Arsenic_ragsa.html 2018.

42. IQBAL J., SHAH M.H. Health Risk Assessment of Metals in Surface Water from Freshwater Source Lakes, Pakistan. Human and Ecological Risk Assessment, 19 (6), 1530, 2013.

43. HOFFMAN F.O., HAMMONDS J.S. Propagation of uncertainty in risk assessments: The need to distinguish between uncertainty due to lack of knowledge and uncertainty due to variability. Risk Analysis, 14 (5), 707, 1994. 